\title{
Mindfulness Meditation Based on Spiritual Care to Reduce Community Anxiety due to the Impact of Pandemic Coronavirus Disease
}

\author{
Siti Nur Hasina* ${ }^{1 *}$, lis Noventi ${ }^{1}$, P. H. Livana ${ }^{2}$ (D), Dodik Hartono ${ }^{3}$ (iD \\ ${ }^{1}$ Departement of Nursing, Faculty of Nursing and Midwifery, Universitas Nahdlatul Ulama Surabaya, Surabaya, East Java, \\ Indonesia; ${ }^{2}$ Nursing Science Program, Sekolah Tinggi IImu Kesehatan Kendal, Kendal, Central Java, Indonesia; ${ }^{3}$ Nursing \\ Science Program, STIKES Hafshawaty Pesantren Zainul Hasan, East Java, Indonesia
}

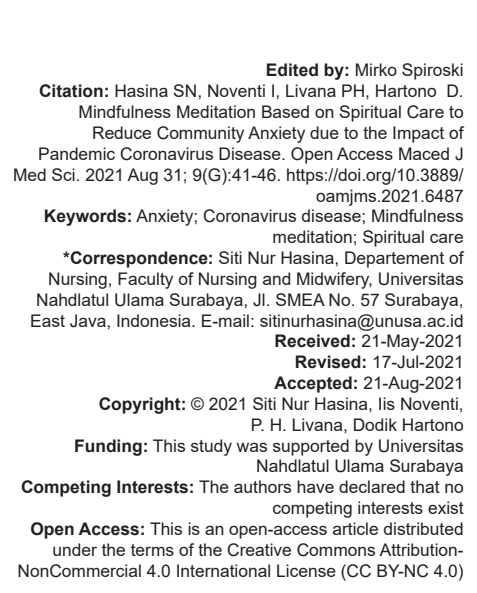

\section{Introduction}

Coronavirus disease (COVID-19) changes human life around the world [1]. The World Health Organization (WHO) announced on January 30, 2020, that COVID-19, which is the cause of acute respiratory syndrome, is becoming a world health emergency [2]. COVID-19 has a long incubation period, easy transmission, high mortality rate, and high lack of intervention [3], [4]. The spread of COVID-19 has spread throughout the world and created a level of fear, uncertainty that has an impact on several aspects of life including mental health [5]. The rapid spread of the Coronavirus or COVID-19 throughout the world has damaged the order of life starting from the economy, social, politics, education, culture, religion, and health.
Various efforts have been made by the Indonesian government by social distancing or physical distancing, washing hands with soap, and staying active at home [6].

Social distancing and staying at home have psychological effects such as depression, anxiety, financial worries, social support, and loneliness [7]. People who are accustomed to living with a high social level physically require distance for fear of spreading the virus through physical contact. So that it causes a stressful situation for some people, especially people who have previously experienced anxiety disorders and it is a common occurrence of anxiety disorders associated with the COVID-19 outbreak in Indonesia [8]. Adaptation to changes that occur in carrying out new activities is not an easy thing. Difficulty dealing with change can increase stress. In addition, the rapid spread of the virus statistical data with the number 
of confirmed positive patients increases and there is death, which has an impact on community anxiety [9]

The number of confirmed COVID-19 sufferers in the world on January 26, 2020, was 98.925.221 with 2.127.294 deaths [10]. The number of confirmed COVID-19 sufferers in Indonesia is 1.012.350 with a death toll of 28.468 people [11]. In East Java, there were 106.162 confirmed cases with a death toll of 7.381 [12]. In Surabaya the cumulative confirmed was 19.510 with confirmation in the care of 250 people [13]. COVID-19 affects mental health as many as $77 \%$ of people experience anxiety, $56 \%$ show depression or depressive symptoms [14].

Conditions thatchange suddenly will make people unprepared to deal with it, especially in the psychological condition of the Indonesian people who experience a lot of anxiety when infected [15]. When mental health declines or is unhealthy, it will cause anxieties that tend to control themselves and basically disturbed mental health begins with feelings of anxiety [16]. Feelings of anxiety originated from COVID-19 that entered Indonesia, many people who contracted it and even lost their lives. Then there was large-scale social restrictions, many people were cutoff from work, went to school from home. Work from home, all recreational areas are closed, religious and cultural activities are carried out at home, activities using transportation modes stop, the economy decreases, causing high levels of stress by causing symptoms of panic, anxiety, fear [17], [18], [19].

Many people experience anxiety in facing major changes during the COVID-19 pandemic [14], [18], [20]. This pandemic is a tense experience, generates intense fear and anxiety and causes regular emotions in adults and children which can be managed with pharmacological and non-pharmacological measures. Handling anxiety during social distancing, self-isolation, and quarantine requires a multi-pronged approach that rests on support, reassurance, obtaining useful information, solving practical problems for patients and using drugs [21]. Individuals with psychiatric disorders may experience exacerbations or worsening of symptoms during a pandemic [8]. Individuals who do not have a history of psychiatric disorders, nonpharmacological actions have good benefits for people who experience anxiety [21].

The hypothalamus pituitary-adrenal axis will be activated by the fear and anxiety caused by the COVID-19 pandemic [22]. The hypothalamus releases corticotrophin-releasing hormone in response to emotional distress then activates the pituitary gland to release adrenocorticotropic hormone, causing the release of cortisol and adrenal glands. Cortisol, a glucocorticoid hormone affects the body such as sleep and wake cycles, glucose metabolism, blood pressure, and increases energy so that individuals can handle stress [23]. Ultimately all cycles result in a depletion of energy in the body, lowering immunity and mental endurance [24].
Experienced anxiety can be reduced by means of mindfulness meditation based on spiritual care which is a non-pharmacological measure [25], [26], [27], [28], [29].

Mindfulness meditation is a meditation practice that focuses on mindfulness techniques through relaxation and concentration exercises [30]. In a study by Hoge et al. (2018), it was shown that mindfulness meditation exercise had an effect on decreasing adrenocorticotropic hormone (ACTH) in the treatment group compared to the control group and that the Area Under the Curve concentration on the hormone $\mathrm{ACTH}$ and inflammatory cytokines had an even greater decrease [31]. A University of California study found that patients who took a mindfulness meditation program for 8 weeks had less depression and anxiety symptoms, better self-control and higher well-being [32].

This research is mindfulness meditation combined with spiritual care. Spiritual care is very important and is one of the pillars that need to be fulfilled so that individuals can become holistically healthy [33], [34]. Spiritual care is a religious practice that includes a relationship with God [35]. Spiritual care can increase patient resilience to mental health crises [36]. In Moeini et al.'s. research, spiritual care through a supportive approach and religious rituals in the form of prayer, call to prayer, pray listening to the Quran, reading tawasul prayers, and spiritual guidance by priests for religions but Islam [26], [37]. There are many studies on mindfulness meditation but not based on spiritual care, this study wants to emphasize spiritual care so that the health felt by the community is comprehensive health both physically, mentally, and spiritually so that there is an acceleration of decreasing the level of anxiety experienced by the community during the COVID-19 pandemic. Seeing the high level of community anxiety due to COVID-19, this study aims to analyze the effect of mindfulness meditation based on spiritual care in reducing community anxiety levels due to the impact of the COVID-19 pandemic.

\section{Methods}

This type of research uses experimental quantitative research using a randomized controlled trial research design. This research was conducted for 4 weeks in January-February 2021 sampling using consecutive sampling technique. The sample in this study is the Surabaya community which is included in the inclusion and exclusion criteria. The inclusion criteria in this study were Surabaya residents aged 15-60 years, experiencing mild to very severe anxiety, not being exposed to COVID-19, and willing to participate in the study for up to 4 weeks. The exclusion criteria in this study were participants who were not willing to participate until the end of this study. In this study, each participant consented by filling out an informed consent form. Participants in this study have the right to withdraw. 
This study was divided into two groups, namely, the intervention group and the control group. The intervention group was given treatment in the form of mindfulness meditation based on spiritual care for 4 weeks, while the control group received no treatment.

The procedure in this research is firstly the researcher obtains a research permit and then the researcher visits the houses of Surabaya residents in the west, east, south and north, residents who agree to have their anxiety level measured. Participants sign the informed consent and participants have the right to resign. In this study, participants received two questionnaires in the form of demographic data (age, gender, profession, and the DASS 42 questionnaire which was retested and had reliability 0.82 . The validity test gets the Cronbach's alpha value is 0.85 [38]. The DASS 42 questionnaire taken number $(2,4,7,9,15$, $19,20,23,25,28,30,36,40,41)$ with normal anxiety assessment indicators with a value range of $0-7$, mild anxiety 8-9, moderate anxiety $10-14$, severe anxiety 15-19, and very severe anxiety >20 [39]. A description of the DASS assessment of one's perceived results starting with the number 0: Absent or never, 1: According to what is experienced to a certain degree, or sometimes, 2: Often, and 3: Very much according to what is experienced or almost every time it is experienced. Before analyzing general data, the data were analyzed for normality first, and then analyzed the data using paired $t$ test and independent $t$ test. spiritual care.

Mindfulness Meditation steps based on

1. Sit with your feet in touch with the earth, feel it calmly or sleep with your hands at your sides

2. Close your eyes, open your attention to the moment that makes anxiety happen to the individual

3. Adjust the breath, then focus on the breath

4. Pay attention to bodily sensations

5. Supportive presence and religious rituals: Build trust, empathy, and honesty between nurses and clients, provide support to clients about problems that occur so that anxiety levels increase, nurses provide a detailed description of COVID-19, when speaking use a supportive approach, invite clients pray, listen to Al-Quran, perform prayers. If you have another religion, listen to soothing religious music or read the scriptures that they believe in Mansurifard et al. [25], Mansurifard et al. [26], Hatmalyakin [27], Hoge et al. [28].

\section{Results}

Table 1 shows that the characteristics of the respondents in this study according to age showed that almost half $(45.9 \%)$ of respondents in the intervention group were at the age of 15-25 years, while for the control group respondents almost half (49.1\%) were at the age of 15-25 years. Characteristics of respondents according to gender showed that most of the respondents $(72.1 \%)$ in the intervention group were female, while almost all of them in the control group $(77.1 \%)$ were male. Most of the respondents in the intervention group (52.5\%) did not work and most of the control group $(60.7 \%)$ doe not work.

Table 1: Characteristics of respondents by age and gender in the treatment and control groups $(n=122)$

\begin{tabular}{|c|c|c|c|c|}
\hline \multirow[t]{3}{*}{ Category } & \multicolumn{4}{|c|}{ Group } \\
\hline & \multicolumn{2}{|c|}{ Intervention Group $(\mathrm{n}=61)$} & \multicolumn{2}{|c|}{ Control Group $(\mathrm{n}=61)$} \\
\hline & $\mathrm{n}$ & $\%$ & $\mathrm{n}$ & $\%$ \\
\hline \multicolumn{5}{|l|}{ Age (years) } \\
\hline $15-25$ & 28 & 45.9 & 30 & 49.1 \\
\hline $26-35$ & 16 & 26.2 & 15 & 24.6 \\
\hline $36-54$ & 11 & 18.0 & 12 & 19.7 \\
\hline$\geq 55$ & 6 & 9.9 & 4 & 6.6 \\
\hline \multicolumn{5}{|l|}{ Gender } \\
\hline Male & 17 & 27.9 & 14 & 22.9 \\
\hline Female & 44 & 72.1 & 47 & 77.1 \\
\hline \multicolumn{5}{|l|}{ Profession } \\
\hline Work & 29 & 47.5 & 24 & 39.3 \\
\hline Does not work & 32 & 52.5 & 37 & 60.7 \\
\hline
\end{tabular}

Table 2 shows that the results of the normality test for the variable level of anxiety pre-est and posttest in the intervention group and control group with the Kolmogorov-Smirnov test obtained a $p>0.05$, which means that the data distribution is normal so that data analysis can be continued using the statistical test paired t-test and independent t-test.

Table 2: Anxiety normality test in the intervention group and control group $(n=61 ; n=61)$

\begin{tabular}{lll}
\hline Group & Anxiety & $\rho^{*}$ \\
\hline Intervention & Pre-test anxiety & 0.200 \\
& Post-test anxiety & 0.157 \\
Control & Pre-test anxiety & 0.099 \\
& Post-test anxiety & 0.200 \\
\hline${ }^{*} p>0.05$ Based on Kolmogorov Smirnov. & &
\end{tabular}

Table 3 shows that the average level of anxiety in the intervention group was 17.18 (severe anxiety) and 17.18 in the control group (severe anxiety) with $p=1.000$ meaning that there was no difference in the average level of anxiety in the intervention group and the control group before intervention.

Table 3: Anxiety in the intervention group and control group before being given the intervention $(n=61 ; n=61)$

\begin{tabular}{lllllll}
\hline Group & Mean & SD & Min & Max & SE & p value \\
\hline Intervention & 17.18 & 4.677 & 10 & 26 & 0.59 & 1.000 \\
Control & 17.18 & 4.514 & 10 & 26 & 0.57 & \\
\hline
\end{tabular}

Table 4 shows that the average level of anxiety in the intervention group is 6.03 (normal anxiety) and 18.06 in the control group (severe anxiety) with $p=0.000$ means that there is a difference in the average level of anxiety in the intervention group and the control group after being given the intervention.

Table 4: Anxiety in the intervention group and the control group after being given the intervention $(n=61 ; n=61)$

\begin{tabular}{lllllll}
\hline Group & Mean & SD & Min & Max & SE & p value \\
\hline Intervention & 6.03 & 2.529 & 2 & 10 & 0.32 & 0.000 \\
Control & 18.06 & 4.269 & 10 & 26 & 0.54 & \\
\hline
\end{tabular}


Based on Table 5, the results of the Paired t-test statistical test obtained $p=0.000$ in the intervention group and obtained $p=0.001$ in the control group, $p<0.05$, it can be concluded that there is a significant change in the level of anxiety before and after being given mindfulness intervention meditation-based spiritual care in the intervention group and the control group.

Table 5: Anxiety level (pre- and post-test) in the intervention group and the control group $(n=61 ; n=61)$

\begin{tabular}{|c|c|c|c|c|c|}
\hline Group & & Mean & St, dev & Count statistics & Significant \\
\hline \multirow{2}{*}{ Intervention } & Pre & 17.18 & 6.677 & 15.4 & 0.000 \\
\hline & Post & 6.03 & 2.529 & & \\
\hline \multirow[t]{2}{*}{ Control } & Pre & 17.18 & 4.514 & -3.4 & 0.001 \\
\hline & Post & 18.06 & 4.269 & & \\
\hline
\end{tabular}

\section{Discussion}

Anxiety is an affective disorder characterized by a deep and continuous feeling of fear or concern, no interference in assessing reality (reality testing ability), personality is still intact, behavior can be disturbed but still within normal limits. There are conscious aspects of anxiety itself such as fear, helplessness, shock, a sense of sin or threat, besides that there are aspects that occur outside of consciousness and cannot avoid unpleasant feelings [29]. In this study, it was found that the 15-25 year age group was still classified as adolescents. In addition, in this study, it was found that most of them were female and did not work. The COVID-19 pandemic has caused mental symptoms or disorders, especially for the most vulnerable population groups. The COVID-19 pandemic increases psychiatric illness and morbidity in different population groups, such as among women, children, adolescents, the elderly, and health professionals due to various aspects of the COVID-19 pandemic such as social distancing policies, negative news, increased numbers confirmed, and died [5], [18].

Anxiety reactions will be different for each individual. For some people, the reaction to anxiety is not always accompanied by a physiological reaction. However, in certain people there will be a complex response by causing temporary physiological reactions such as a faster heart rate, sweating, stomach pain, headaches, itching and other symptoms. After a person begins to feel anxiety, the self-defense system will then reassess the threat accompanied by efforts to overcome, reduce or eliminate the feeling of being threatened. Someone can use self-defense (defense mechanism) by increasing cognitive or motor activity [18]. Anxiety usually comes from the perception of uncontrolled events, so that individuals will focus on controlled actions [40].

The average level of anxiety before doing the spiritual care-based mindfulness meditation intervention in the intervention group 17.28 (severe anxiety) and 17.18 in the control group (severe anxiety) with $p=1.000$ which means there is no difference in the average level of anxiety while after it was given The intervention obtained an average level of anxiety in the intervention group 6.03 (normal anxiety) and 18.06 in the control group (severe anxiety) with $p=0.000$, which means that there is a difference in the average level of anxiety in the intervention group and the control group after being given the intervention. This study combines mindfulness meditation with spiritual care, spiritual care in the form of the role of religion, prayer, support for religious rituals and supportive presence (non-religious rituals) have a major influence in reducing anxiety levels [37]. The results of this study are consistent with research by Zwan et al. that mindfulness meditation can reduce anxiety levels in adult patients [41], [42]

Mindfulness meditation focuses on an individual's personal experiences, such as breath, body sensations, feelings, and thoughts [43]. Mindfulness techniques serve to present problems to present events. In addition, mindfulness meditation has benefits for mental conditions, namely, in the form of mental calmness as well as relaxation and converting negative energy into positive energy so that it can reduce anxiety, stress, and depression [44], [45]. Spiritual care is one of the most important aspects for health, the spiritual aspect has a harmonious relationship and is interconnected with life stability and inner strength, provides peace, strengthens relationships with oneself, community gods, and the environment. Spiritual care is the only force in coordinating the physical, psychological and social dimensions [25], [46].

Spiritual care when combined with other interventions will be able to speed up recovery from an illness, improve spiritual health and control anxiety especially masayrakat future pandemic COVID-19 [47], [48]. Mindfulness meditation is a practice that supports health professionals, patients, caregivers, and the general community during times of crisis such as the global pandemic caused by COVID-19. This practice is based on awareness and spiritual care, is low cost and low risk. This exercise has been shown to have an impact on quality of life and biological outcomes in many different populations including both COVID-19 and cancer patients and this practice can be practiced on a daily basis so as to improve mental health especially anxiety [26], [45], [49].

\section{Conclusion}

The provision of mindfulness meditation based on spiritual care interventions has a positive effect on reducing public anxiety during the COVID-19 pandemic so that this therapy can be used by all ages and has 
no adverse effects. The results of this study can also be used as a reference for nurses' actions in providing non-pharmacological therapy that can be done independently.

\section{Acknowledgments}

The research team would like to thank all participants in this study and thank the Universitas Nahdlatul Ulama Surabaya for supporting and funding this research.

\section{References}

1. Habibi A. Normal Baru Pasca Covid-19. Vol. 4. Adalah: Buletin Hukum dan Kwadilan; 2020.

2. World Health Organization. Rolling Updates on Coronavirus Disease (COVID-19). Geneva: World Health Organization; 2020. Available from: https://www.who.int/emergencies/ diseases/novel-coronavirus-2019/events-as-they-happen. [Last accessed on $2021 \mathrm{Feb} 26]$.

3. Linton M, Kobayashi T, Yang Y, Hayashi K, Akhmetzhanov AR, Jung $\mathrm{S}$, et al. Incubation period and other epidemiological characteristics of 2019 novel coronavirus infections with right truncation: A statistical analysis of publicly available case data. J Clin Med. 2020;9:538. https://doi.org/10.3390/jcm9020538

4. Shereen MA, Khan S, Kazmi A, Bashir N, Siddique B. COVID-19 infection: Origin, transmission, and characteristics of human coronaviruses. J Adv Res. 2020;24:91-8. https://doi. org/10.1016/j.jare.2020.03.005

PMid:32257431

5. Machado DB, Alves FJ, Teixeira CS, Rocha A, Castro-deAraujo LF, Sing A, et al. Effects of COVID-19 on Anxiety, Depression and Other Mental Health Issues: A Worldwide Scope Review; 2020. https://doi.org/10.21203/rs.3.rs-58186/v1

6. Jarnawi. Mengelola Cemas Di Tengah Pandemik Corona. Jurnal At-Taujih Bimbingan dan Konseling Islam. Vol. 3 No. 1 JanuariJuni; 2020. Available from: http://www.jurnal.ar-raniry.ac.id/ index.php/taujih. [Last accessed on 2021 Feb 26]. https://doi. org/10.22373/taujih.v3i1.7216

7. Tull MT, Edmonds KA, Scamaldo KM, Richmond JR, Rose JP, Gratz KL, et al. Psychological outcomes associated with stayat-home orders and the perceived impact of COVID-19 on daily life. Psychiatry Res. 2020;289:113098. https://doi.org/10.1016/j. psychres.2020.113098

PMid:32434092

8. Wulandari P, Hidayar R. General anxiety disorder-related coronavirus disease-19 Outbreak in Indonesia: A case reports. Maced J Med Sci. 2020;8:36-8. https://doi.org/10.3889/ oamjms.2020.4762

9. Aufar AF, Raharjo ST. Relaxation activities as coping with stress during the Covid-19 pandemic. J Kolab Resolusi Konflik. 2020;2:157-63. https://doi.org/10.24198/jkrk.v2i2.29126

10. World Health Organization. Global Situation. Geneva: World Health Organization; 2020. Available from: https://covid19. who.int/?gclid=EAlalQobChMI8IjVq G57gIVBh4rCh22bg8jEAAYASAAEgJVQ_D_BwE. [Last accessed on 2021 Jan 20].

11. Komite Penanganan COVID-19 dan Pemulihan Ekonomi Nasional. Peta Sebaran; 2021. Available from: https://www. covid19.go.id/peta-sebaran. [Last accessed on 2021 Jan 26]. https://doi.org/10.31228/osf.io/5h9jd

12. Pemerintah Provinsi Jawa Timur. JATIM Tanggap COVID-19; 2021. Available from: http://www.infocovid19.jatimprov.go.id. [Last accessed on 2021 Jan 26].

13. Pemerintah Kota Surabaya. Surabaya Lawan COVID-19; 2021 Available from: https://www.lawancovid-19.surabaya.go.id. [Last accessed on 2021 Jan 26].

14. Machado DB, Alves FJ, Teixeira CS, Rocha AS, Castro-deAraujo LF, Singh A, et al. Effects of COVID-19 on Anxiety, Depression and other Mental Health Issues: A Worldwide Scope Review; 2020. https://doi.org/10.21203/rs.3.rs-58186/v1

15. Fitria L. Cognitive behavior therapy counseling untuk mengatasi anxiety dalam masa pandemi Covid-19. ALIRSYAD. 2020;10(1):23-9.

16. Setyaningrum W, Yanuarti HA. Pengaruh Covid-19 terhadap kesehatan mental masyarakat di kota malang. J IImu Sosial Pendidikan. 2020;4:1580. https://doi.org/10.36312/jisip. v4i4.1580

17. Iqbal M, Rizqulloh L. Early detection of mental health due to the COVID-19 pandemic at the Unnes sex care community through the self-reporting questionnaire method. J Sains Teknol Masyarakat Jejaring. 2020;3(1):20-4. https://doi.org/10.24167/ praxis.v3i1.2730

18. Vibriyanti D. Community mental health: Managing anxiety amidst the Covid-19 pandemic. J Kependudukan Indones. 2020:69-74. https://doi.org/10.14203/jki.v0i0.550

19. Aufar AF, Raharjo ST. Relaxation activities as coping with stress during the COVID-19 pandemic. J Kolaborasi Resolusi Konflik. 2020;2(2):157. https://doi.org/10.24198/jkrk.v2i2.29126

20. Sari I. Analisis dampak pandemi covid-19 terhadap kecemasan masyarakat: Literature review. Bina Gen. 2020;12(1):69-76. https://doi.org/10.35907/bgjk.v12i1.161

21. Chaudhury S, Pooja V, Thakur M, Saldanha D. COVID 19 pandemic anxiety and its management. Acta Sci Neurol. 2020;3:39-41. https://doi.org/10.31080/asne.2020.03.0208

22. Raony I, de Figueiredo CS, Pandolfo P, Giestal-de-Araujo E, Oliviera-Silva Bomfim P, Savino W. Psycho-neuroendocrine immune interactions in COVID-19: Potential impacts on mental health. Front. Immunol. 2020;11:1170. https://doi.org/10.3389/ fimmu.2020.01170

PMid:32574266

23. Roulston A, Montgomery L, Campbell A, Davidson G. Exploring the impact of mindfulness on mental well-being, stress and resilience of undergraduate social work students. Soc Work Educ. 2018;37:157-72. https://doi.org/10.1080/02615479. 2017.1388776

24. Oken BS, Goodrich E, Klee D, Memmott T, Proulx J. Predictors of improvements in mental health from mindfulness meditation in stressed older adults. Altern Ther Health Med. 2018;24(1):48-55. https://doi.org/10.1007/s12671-016-0640-7 PMid:29332020

25. Mansurifard F, Ghaljaei F, Navidian A. The effect of spiritual care on the spiritual health of adolescents with cancer: A preexperimental study. Med Surg Nurs J. 2019;8(4):e100567. https://doi.org/10.5812/msnj.100567

26. Moeini M, Taleghani F, Mehrabi T, Musarezaie A. Effect of a spiritual care program on levels of anxiety in patients with leukemia. Iran J Nurs Midwifery Res. 2014;19(1):88-93. PMid:24554966

27. Hatmalyakin D. Pengaruh Terapi Mindfulness Meditation Dan Aromaterapi Terhadap Penurunan Kecemasan Perawat Pada Penanganan Kegawatdaruratan Kardiovaskular Di Rsud 
Dr. Soedarso Pontianak. Magister thesis, Universitas Brawijaya; 2019.

28. Hoge EA, Bui E, Marques L, Metcalf CA, Morris LK, Robinaugh DJ, et al. Randomized controlled trial of mindfulness meditation for generalized anxiety disorder: Effects on anxiety and stress reactivity. J Clin Psychiatry. 2013;74(8):786-92. https://doi.org/10.4088/jcp.12m08083

PMid:23541163

29. Breedvelt JJ, Amanvermez $\mathrm{Y}$, Harrer M, Karyotaki $\mathrm{E}$, Gilbody S, Bockting CL, et al. The effects of meditation, yoga, and mindfulness on depression, anxiety, and stress in tertiary education students: A meta-analysis. Front Psychiatry. 2019;10:193. https://doi.org/10.3389/fpsyt.2019.00193 PMid:31068842

30. Liu HL, Liu Q, Xie HY, Wang FZ, Xie YM, Li ZH. Effect of meditation training on postoperative pain in school-age children with cardiac diseases. Chin J Nurs. 2011;46:745-7.

31. Hoge EA, Bui E, Palitz SA, Schwarz NR, Owens ME, Johnston JM, et al. The effect of mindfulness meditation training on biological acute stress responses in generalized anxiety disorder. Psychiatry Res. 2018;262:328-32. https://doi. org/10.1016/j.psychres.2017.01.006

PMid:28131433

32. Afandi NA. The effect of mindfulness training on increasing selfcontrol of high school students. J PAMATOR. 2016;5(1):2493. https://doi.org/10.21927/jnki.2018.6(2).56-67

33. Hasina SN, Sukartini T, Setiyowati E. Effect of sleep hygiene and deep breathing exercise with spiritual care on sleep quality and quality of life of hemodialysis patient in ahmad yani islamic hospital Surabaya. J Ners Kebidanan Indones. 2019;6(2):140-51.

34. Hasina S, Khafid M. Pengaruh sleep hygiene dan ergonomic exercise berbasis spiritual care terhadap kadar asam urat dan kualitas hidup penderita arthritis gout. J Keperawatan. 2020;12(2):203-16.

35. Puchalski CM. Spirituality and end-of-life care: A time for listening and caring. J Palliat Med. 2002;5(2):289-94. PMid:12006231

36. Meraviglia M. Effects of spirituality in breast cancer survivors. Oncol Nurs Forum. 2006;33(1):E1-7. PMid: 16470229

37. Moeini M, Ghasemi TM, Yousefi H, Abedi H. The effect of spiritual care on spiritual health of patients with cardiac ischemia. Iran J Nurs Midwifery Res. 2012;17(3):195-9. PMid:23833611

38. Afzali A, Delavar A, Borjali A, Mirzamani M. Psychometric properties of DASS-42 as assessed in a sample of Kermanshah high school students. J-Res Behav Sci. 2007;5:81-92.
39. Asgharimoghadam MA, Saed F, Dibajnia $P$, Zangeneh JA Preliminary study of the reliability and validity of the depression, ananv anxiety, and stress scale on non-clinical samples. Daneshvar-e-Raftar. -2009;31:23-38.

40. Shin KE, Newman MG. Self and otherperceptions of interpersonal problems: Effects of generalized anxiety, social anxiety, and depression. Anxiety Disord. 2019;65:1-10. https:// doi.org/10.1016/j.janxdis.2019.04.005

PMid:31054457

41. Zwan JE, de Vente W, Huizink AC, Bögels SM, de Bruin EI. Physical activity, mindfulness meditation, or heart rate variability biofeedback for stress reduction: A randomized controlled trial. Appl Psychophysiol Biofeedback. 2015;40(4):257-68. https:// doi.org/10.1007/s10484-015-9293-x

PMid:26111942

42. Bohlmeijer E, Prenger R, Taal E, Cuijpers P. The effect of mindfulness-based stress reduction therapy on mental health of adults with a chronic medical disease: A meta analysis. J Psychosom Res. 2010;68(6):539-44. https://doi.org/10.1016/j. jpsychores.2009.10.005 PMid:20488270

43. Germer CK. The Mindful Path To SelfCompassion. United State of America: The Guilford Press; 2009.

44. Zollars I, Poirier TI, Pailden J. Effects of mindfulness meditation on mindfulness, mental-wellbeing and perceived stress. Curr Pharm Teach Learn. 2019;11(10):1022-8. https://doi. org/10.1016/j.cptl.2019.06.005 PMid:31685171

45. Flett JA, Hayne H, Riordan BC, Thompson LM, Conner TS. Mobile mindfulness meditation: A randomized controlled trial of the effect of two popular apps on mental health. Mindfulness. 2018;10:863-79. https://doi.org/10.1007/s12671-018-1050-9

46. Rahimi N, Nouhi E, Nakhaee N. Spiritual health among nursing and midwifery students at kerman university of medical sciences. J Hayat. 2014;19(4):74-81. https://doi.org/10.29252/ ijn.27.90.91.150

47. Fallah R, Golzari M, Dastani M, Zahiredin A, Nafisi N, Akbari ME. Spirituality, Hope and Mental Health in Breast Cancer Patients. In: Palliative Medicine in the $21^{\text {st }}$ Century Congress;2010. p. 14-7.

48. Breitbart W, Rosenfeld B, Gibson C, Pessin H, Poppito S, Nelson C, et al. Meaning-centered group psychotherapy for patients with advanced cancer: A pilot randomized controlled trial. Psychooncology. 2010;19(1):21-8. https://doi.org/10.1002/ pon. 1556 PMid:19274623

49. Bauer-Wu S. Mindfulness meditation. Oncology (Williston Park, NY). 2010;24(10 Suppl):36-40.

PMid:21275324 